Nippon Suisan Gakkaishi $\quad$ 79(5), 888 (2013)

\title{
シンポジウム記録 水産における光利用技術と基礎研究の動向
}

\section{III-3. 光照射とシオミズツボワムシの 増殖および栄養環境}

\author{
田中賢二 \\ 近畿大学産業理工学部
}

III-3. Relation between growth of rotifer and nutrition condition under photoirradiation

KENJI TANAKA

Faculty of Humanity-Oriented Science and Engineering, Kinki University, Iizuka, Fukuoka 820-8555, Japan

\section{1. はじめに}

著者らは動物性初期餌料であるシオミズツボワムシの 生産効率化について研究しており，1）その過程でビタミ ン $\mathrm{B}_{12}$ を含有しない淡水クロレラを給慨した場合， L 型 ワムシ Brachinonus plicatilis（以下ワムシと称す）は遮 光下では増殖できないものの光照射下では増殖可能なこ とを見出した。そこで，光照射がワムシ増殖に及ぼす影 響，とくに安価な䬶料である生パン酵母給䬣培養に打け る増殖促進効果, 打よびワムシ培養水中でのビタミン $\mathrm{B}_{12}$ 合成に対する影響について検証した。

\section{2. 光照射下でのワムシの増殖}

小型ガラス水槽を用いてエアーポンプから通気しつつ $24^{\circ} \mathrm{C}$ でワムシの培養試験を行った。LED パネルより青 色光 $470 \mathrm{~nm}$, 緑色光 $525 \mathrm{~nm}$, 赤色光 $660 \mathrm{~nm}$ および白 色光を様々な光量子束密度で照射し, 各試験区における ワムシ増殖量を比較した。ワムシ用䬣料には市販のビタ ミン $\mathrm{B}_{12}$ 含有濃色淡水クロレラ（以下クロレラと称す） もしくは圧搾生パン酵母（以下パン酵母と称す）を用い た。なお, パン酵母給餌試験では, 培養海水（塩分 20 \% ）に硫酸コバルト $100 \mathrm{ppb}$ を添加した。

結果として, クロレラ給飭培養では遮光下よりも光照 射下のほうがワムシの増殖は良く, 青色光のような波長 が短い光のほうがワムシ個体群密度は高くなる，あるい は増殖が速くなる傾向が見られた。ワムシ増殖に最適な 光量は, 光量子束密度で $3.0 \mu \mathrm{mol} \cdot \mathrm{m}^{-2} \bullet \mathrm{s}^{-1}$ 前後であり, $10.0 \mu \mathrm{mol} \cdot \mathrm{m}^{-2} \bullet \mathrm{s}^{-1}$ 以上では個体群密度の増加は良くな かった。光照射下での個体群密度の増加はパン酵母給餌 培養でいっそう顕著であり，青色光 $3.0 \mu \mathrm{mol} ・ \mathrm{~m}^{-2} \bullet \mathrm{s}^{-1}$
照射では 600 個体/ $\mathrm{mL}$ を超える個体群密度が得られ， 増殖速度もクロレラ給慨と同等だった。

\section{3. 光照射によるビタミン $\mathrm{B}_{12}$ 合成量増大}

ワムシ培養水中にはワムシ増殖必須因子であるビタミ ン $\mathrm{B}_{12}$ を合成する細菌が出現するとする報告が幾つもあ り, 光照射下でのワムシの良好な増殖にもビタミン $\mathrm{B}_{12}$ 合成細菌の関与が考えられる。実際, 遮光時に較べて, 青色光照射下ではパン酵母を給慨した時の培養水懸濁物 中のビタミン $\mathrm{B}_{12}$ 合成量が増大していた。また，この時 の培養水から細菌を 100 株分離して調べたところ, 分 離菌株の 4 割近くにビタミン $\mathrm{B}_{12}$ 合成能が認められた。 一方, 滅菌海水とこれでよく洗浄したワムシを用いて培 養を行うと, 光照射下でもワムシ個体群密度の伸びは非 常に小さいものとなった。

光照射下でのワムシ増殖密度の増加は, 培養水中のビ タミン $\mathrm{B}^{12}$ 合成量増大によるものと推察されたが, 現時 点では光照射下でビタミン $\mathrm{B}^{12}$ 合成量が増える菌株を特 定できておらず，そのような微生物の報告例もない。し かしながら, やはりワムシ増殖因子であるビタミン $\mathrm{A}$ については光照射により合成が促進される例が幾つも報 告されており, 促進機構解明も進みつつある。ビタミン $\mathrm{A}$ や $\mathrm{B}^{12}$ の合成量が光照射下で増加する細菌菌株の分離・ 特定が今後の研究進展の大きな鍵になると考えられる。

一方で，光は携卵などワムシ自身の生活活動には必ず しも良くないことが他の研究者によって報告されてい る。光照射がワムシ生産の効率化に利用できる可能性が あるか否かについては, 株のタイプや給慨ほか飼育履 歴, 餌料の種類その他栄養条件, 通気・pH・DOなど 培養環境や照射光量, 細菌フローラの構成など多くの要 因も考慮しつつ慎重に研究を重ねていく必要がある。

\section{文献}

1) 吉村研治, 岩田 剛, 田中賢二, 北島 力, 石崎文彬. 非 解離アンモニア抑制のための $\mathrm{pH}$ 制御によるシオミズッボ ワムシの高密度培養. 日水誌 1995; 61: 602-607.

2) Yoshimatsu $T$, Higuchi $T$, Hamasaki Y, Tanaka K. Preliminary trials on the effect of lighting for the population growth of the rotifer, Brachionus plicatilis. J. Agri. Res. Quaterly. 2008; 42: 131-136. 